Пархоменко-Куцевіл Оксана Ігорівна доктор наук 3 державного управління, професор, завідувач кафедри публічного управління та адміністрування, Університету Григорія Скоровороди в Переяславі, вул. Сухомлинського, 30, м. Переяслав, 08400, тел.: (050) 922-15-35, https://orcid.org/0000-0002-0758-346X

\title{
ПРОБЛЕМИ РЕАЛІЗАЦІЇ МЕХАНІЗМІВ КООРДИНАЦІЇ ДІЯЛЬНОСТІ ОРГАНІВ ДЕРЖАВНОЇ ВЛАДИ УКРАЇНИ В УМОВАХ ПАНДЕМІї COVID-19
}

Анотація. У дослідженні здійснено аналіз проблем реалізації механізмів координації діяльності органів державної влади України в умовах пандемії COVID-19. Автором зазначено, що на сьогодні назріла необхідність координації органів державної влади, які забезпечують запобігання поширенню короновірусної інфекції та мінімізації наслідків пандемії COVID19, зокрема: формування єдиної інформаційної політики щодо інформування громадськості та населення про заходи, які здійснюються органами державної влади; формування єдиної стратегії імунізації населення країни; перерозподіл фінансування та виділення коштів із Державного бюджету України на наукові розробки в галузі вивчення короновірусної інфекції та розробки ліків та вакцин; формування форсайт-досліджень проблем розповсюдження короновірусної інфекції із залученням провідних наукових установ, науковців та системи органів державної влади; регламентація та впровадження стандартів діяльності для дистанційної роботи для державних службовців; запровадження інформаційних технологій у надання адміністративних послуг. Обгрунтовано, що Національний штаб протидії COVID-19 повинен здійснювати координацію діяльності органів державної влади України в умовах пандемії COVID-19. Автором проаналізовані основні сфера координації діяльності органів державної влади, зокрема: допомога особам, громадянам (їх колективам, суспільству в цілому) у зв'язку з поширенням захворювання, а також інші дії; допомога приватному бізнесу, який є основою економіки країни; формування прогнозів поширення короновірусної інфекції та наслідків пандемії COVID-19 та створення при Національному штабі протидії COVID-19 спеціального підрозділу, який би здійснював форсайтдослідження; формування дієвої державної інформаційної політики, спрямованої на надання правдивої інформації щодо захворілих осіб, заходи, які здійснюють органи державної влади та місцевого самоврядування для запобігання поширенню короновірусної інфекції та мінімізації наслідків пандемії COVID-19, надання експертних оцінок питання імунізації населення 
та формування суспільного імунітету; формування єдиних ресурсів по наданню важливих адміністративних послуг он-лайн для населення; формування нормативно-правових засад запровадження телемедицини в Україні як основи забезпечення надання медичних послуг в умовах пандемії COVID-19 та у період техногенних катастроф.

Ключові слова: механізми координації діяльності органів державної влади України, пандемія COVID-19, формування державної інформаційної політики, форсайт-дослідження, надання адміністративних послуг.

Parkhomenko-Kutsevil Oksana Ihorivna Doctor of Public Administration, Professor, Head of the Department of Public Administration and Administration of Hryhorii Skovoroda University in Pereiaslav, Sukhomlinskoho St., 30, Pereyaslav, 08400, tel.: (050) 922-15-35, https://orcid.org/0000-0002-0758-346X

\title{
PROBLEMS OF IMPLEMENTATION OF MECHANISMS OF COORDINATION OF ACTIVITIES OF GOVERNMENT AUTHORITIES OF UKRAINE IN THE CONDITIONS OF THE COVID-19 PANDEMIC
}

\begin{abstract}
The study analyzes the problems of implementation of mechanisms for coordinating the activities of public authorities of Ukraine in the pandemic COVID-19. The author notes that today there is a need to coordinate public authorities to prevent the spread of coronavirus infection and minimize the effects of the COVID-19 pandemic, in particular: formation of a unified strategy for immunization of the country's population; redistribution of funding and allocation of funds from the State Budget of Ukraine for research in the field of coronavirus infection and development of drugs and vaccines; formation of foresight research on the spread of coronavirus infection with the involvement of leading scientific institutions, scientists and the system of public authorities; regulation and implementation of standards for remote work for civil servants; introduction of information technologies in the provision of administrative services. The article substantiates that the National Headquarters of COVID-19 should coordinate the activities of public authorities of Ukraine in the context of the COVID-19 pandemic. The author analyzes the main areas of coordination of public authorities, in particular: assistance to individuals, citizens (their teams, society as a whole) in connection with the spread of the disease, as well as other actions; assistance to private business, which is the basis of the country's economy; formation of forecasts for the spread of coronavirus infection and the consequences of the COVID-19 pandemic and the establishment of a special unit at the National Headquarters for COVID-19 to conduct foresight research; formation of an effective state information policy aimed at providing truthful information about sick people, measures taken by public authorities and local governments to prevent the spread of coronavirus infection and minimize the effects of the COVID-19 pandemic, providing expert assessments of immunization and public immunity; formation of common resources
\end{abstract}


for the provision of important online administrative services for the population; formation of normative and legal bases for the introduction of telemedicine in Ukraine as a basis for ensuring the provision of medical services in the context of the COVID-19 pandemic and in the period of man-made disasters.

Keywords: mechanisms of coordination of activity of state authorities of Ukraine, pandemic COVID-19, formation of the state information policy, foresight research, rendering of administrative services.

Постановка проблеми. Пандемія COVID-19 для кожної держави стала додатковим випробуванням на міцність не тільки для системи охорони здоров'я, але й для існуючої моделі інституційної взаємодії різних рівнів публічної влади, областю формування політичної відповідальності громадських суб'єктів за прийняті рішення.

Необхідно розуміти, що коронавірусна інфекція за своїми наслідками явище багатоаспектне. Пандемія зачіпає практично всі без винятку сфери життєдіяльності сучасного суспільства. Державне управління у різних сферах суспільного життя здійснюється найрізноманітнішими, спеціалізованими органами державної влади. Відповідно діяльність зазначених органів державної влади із запобігання поширенню короновірусної інфекції, подолання несприятливих наслідків та мінімізації наслідків пандемії COVID-19 є різноплановою, різноманітною, яка поділена за напрямами життя i управління і об'єктивно потребує узгодження і координації.

Звичайно, вирішення питання запобігання поширенню короновірусної інфекції та мінімізації наслідків пандемії - це спільні дії Уряду України, Верховної Ради України, Президента України, громадськості, активних громадян. Попередній досвід запобігання та мінімізації пандемії COVID-19 продемонстрував неспроможність органів державної влади вирішити це питання, адже ситуація 3 розповсюдженням короновірусної інфекції повторюється, навіть запроваджують карантинних заходів не дають реальних результатів. Тому, на даний час актуалізується питання визначення механізмів координації діяльності органів державної влади україни в умовах пандемії COVID-19.

Аналіз останніх досліджень i публікацій. Проблеми запобігання поширенню короновірусної інфекції та мінімізації наслідків пандемії COVID-19 аналізують, зокрема, Г.Андрощук, Я. Базилюк, В. Борщ, Т.Гейко, В. Горбулін, Ю. Даник, І. Джалладова, А.Калініна, Камінський, Т.Кемарська, Н. Колісніченко, Т.Крушельницька, І.Петров, Т.Романенко, О. Чорний, О. Шевчук та ін.

Метою статті $\epsilon$ здійснення системного аналізу проблеми реалізації механізмів координації діяльності органів державної влади україни в умовах пандемії COVID-19.

Виклад основного матеріалу. На думку О. Чорного, серед першочергових завдань органів державної влади, які здійснюють політику у 
сфері запобігання поширенню короновірусної інфекції та мінімізації наслідків пандемії COVID-19, зокрема: проводити періодичний перегляд введених обмежень, здійснювати моніторинг їх наслідків і коригувати обсяг обмежень відповідно до змін епідеміологічних ризиків. Керівники органів державної влади повинні швидко і рішуче виступати з публічним засудженням будь-яких форм підбурювання до дискримінації, ворожнечі або переконань, слід у попереджувальному порядку підтримувати установки, що заохочують солідарність, надію і інтеграцію всіх осіб. Потрібно забезпечити, щоб в умовах більш активного використання соціальних мереж та інших онлайн-технологій забезпечувався належний захист недоторканності приватного життя i персональних даних. Слід створити постійно діючі канали зв’язку і контактні пункти на національному та місцевому рівні 3 метою зміцнення довіри між державою і представниками різних громадських організацій [1].

Пандемія COVID-19 стала таким собі «лакмусовим папірцем», що дозволила по-новому поглянути на функціонування всієї безпекової сфери країни, зокрема координації органів державної влади. Цей зовнішній вплив дозволив зайвий раз впевнитися управлінцям у необхідності розуміння взаємного зв'язку всіх складових безпекових систем [2].

Саме пандемія COVID-19 продемонструвала відсутність співпраці між органами державної влади, неефективність державної політики у сфері охорони здоров'я України, спрямованої на запобігання поширенню короновірусної інфекції та мінімізації наслідків пандемії COVID-19. Так, до сьогодні не прийнято законодавчий документ, який би формував єдину стратегію забезпечення державної політики у сфері охорони здоров'я України, спрямованої на запобігання поширенню короновірусної інфекції та мінімізації наслідків пандемії COVID-19. Дана Стратегія повинна бути прийняття та реалізована вже сьогодні, адже наслідки пандемії COVID-19 стосуються всіх сфер життєдіяльності суспільства та кожного громадянина (зокрема. економіки, соціального захисту, працевлаштування, отримання важливих адміністративних послуг, пересування в межах країни та межах світу, комунікації, освітні послуги тощо). Крім того, хвилеподібне виникнення та розвиток короновірусної інфекції, мутації такої інфекції вимагають комплексних досліджень та прогнозування подальшого розвитку короновірусної хвороби з урахуванням імунізації населення, вивчення реакції різних груп населення тощо. А це в свою чергу вимагає координації органів державної влади та формування єдиних підходів, механізмів та інструментів забезпечення реалізації державної політики у сфері охорони здоров'я України, спрямованої на запобігання поширенню короновірусної інфекції та мінімізації наслідків пандемії COVID-19.

Крім того, визнання пандемії як основи формування дієвої реалізації механізмів координації діяльності органів державної влади україни в умовах пандемії COVID-19, що є небезпечними для життя і здоров’я людей можна обгрунтувати тим, що подібне явище має дуальну природу: $\epsilon$ певним 
каталізатором процесів налагодження взаємодії між органами державної влади і удосконалення нормативного поля, що забезпечує цю взаємодію, а також $є$ індикатором, що свідчить про прорахунки в стратегічному управлінні в безпековій сфері [2].

На сьогодні назріла необхідність координації органів державної влади, які забезпечують запобігання поширенню короновірусної інфекції та мінімізації наслідків пандемії COVID-19, зокрема:

формування єдиної інформаційної політики щодо інформування громадськості та населення про заходи, які здійснюються органами державної влади;

формування єдиної стратегії імунізації населення країни;

перерозподіл фінансування та виділення коштів із Державного бюджету України на наукові розробки в галузі вивчення короновірусної інфекції та розробки ліків та вакцин;

- формування форсайт-досліджень проблем розповсюдження короновірусної інфекції із залученням провідних наукових установ, науковців та системи органів державної влади;

регламентація та впровадження стандартів діяльності для дистанційної роботи для державних службовців;

- запровадження інформаційних технологій у надання адміністративних послуг.

20 жовтня 2020 р. постановою Верховної Ради України було рекомендовано Президенту України утворити нову інституцію - Національний штаб протидії COVID-19 та очолити його для організації оперативного реагування на поширення коронавірусної хвороби (COVID-19) в Україні, підвищення спроможності національної системи охорони здоров'я, запровадження комплексної системи захисту вітчизняної економіки від наслідків пандемії, розробки та втілення ефективної безпекової стратегії України в умовах нових глобальних біологічних викликів [3].

Зазначена інституція має бути створена ще на початку 2020 року, адже результати мінімізації та протидії 3 COVID-19 продемонструвала неможливість державних інституцій вирішити це питання. I саме цей Національний штаб протидії COVID-19 повинен здійснювати координацію діяльності органів державної влади України в умовах пандемії COVID-19.

На нашу думку, координація діяльності органів державної влади України в умовах пандемії COVID-19 повинна бути спрямована на наступне.

Перша сфера координації діяльності органів державної влади - це допомога особам, громадянам (їх колективам, суспільству в цілому) у зв'язку з поширенням захворювання, а також інші дії. Насамперед, це допомога конкретним фізичним особам, які опинилися у складній життєвій ситуації у зв'язку 3 пандемією. Ця допомога спочатку складається у сприянні поверненню громадян України до України, їх карантинна перевірка та, у разі потреби, лікування, так само як і лікування тих фізичних, що перебувають на 
території України, які заразилися коронавірусом. Тут також доцільна індивідуальна матеріальна, психологічна тощо допомога таким особам.

Зазначене передбачає формування банків даних на регіони 3 метою надання матеріальної, психологічної допомоги, допомоги у працевлаштуванні (якщо особа втратила роботу), формування списків осіб, які опинилися в складних життєвих обставинах у зв'язку з пандемією COVID-19 тощо. I саме регіональні органи державної влади у співпраці з центральними органами державної влади забезпечують таку допомогу та виділення матеріального забезпечення. Ця співпраця передбачає залучення як органів державної влади так органів місцевого самоврядування.

Наступна сфера координації діяльності органів державної влади - це допомога приватному бізнесу, який є основою економіки країни. Це має бути, насамперед, зниження державного тягаря та тиску на бізнес: мораторій перевірок контролюючими та правоохоронними органами (за винятком, зрозуміло, перевірок повідомлень про злочини), призупинення нарахування будь-яких податків, пені та санкцій, пом'якшення режиму роботи підприємств, що торгують продуктами харчування, аптек тощо. Якщо організація (підприємець) орендує, наприклад, у заклади комунальної (державної) власності, то при закритті кінотеатру «на карантин» не може бути і мови про стягнення за цей період будь-якої орендної плати до державного бюджету.

Наступний напрям співпраці органів державної влади - це формування прогнозів поширення короновірусної інфекції та наслідків пандемії COVID-19. Зокрема, створення при Національному штабі протидії COVID-19 спеціального підрозділу, який би здійснював форсайт-дослідження. Саме форсайт-дослідження вимагають тісної співпраці Міністерства охорони здоров'я України, Національної служби здоров'я України, Державної служби України 3 надзвичайних ситуацій, Міністерства освіти i науки України, Міністерства соціальної політики України, Державного центру зайнятості та ін. Зазначені форсайт-дослідження мають бути спрямованими на прогнозування подальших виникнень короновірусної інфекції; прогнозування можливих отримувачів соціальних допомог при умові наступної хвилі короновірусної інфекції; прогнозування кількості осіб, які потребуватимуть послуг 3 працевлаштування; прогнозування потреб у подальшому запроваджені дистанційного навчання; прогнозування потреб у формування резервних активів для запобігання виникненню та розповсюдженню короновірусної інфекції тощо.

Ще одна сфера координації діяльності органів державної влади - це формування дієвої державної інформаційної політики, спрямованої на надання правдивої інформації щодо захворілих осіб, заходи, які здійснюють органи державної влади та місцевого самоврядування для запобігання поширенню короновірусної інфекції та мінімізації наслідків пандемії COVID-19, надання експертних оцінок питання імунізації населення та формування суспільного імунітету. Це передбачає спільні дії Міністерства охорони здоров’я України, 
Національної служби здоров’я України, Міністерства цифрової трансформації України та інших органів державної влади.

Важлива сфера координації діяльності органів державної влади - це формування єдиних ресурсів по наданню важливих адміністративних послуг он-лайн для населення. Потребує формування єдиної платформи надання всіх державних та адміністративних послуг населенню, наприклад через додаток «Дія».

Наступною сферою координації діяльності органів державної влади $є$ формування нормативно-правових засад запровадження телемедицини в Україні як основи забезпечення надання медичних послуг в умовах пандемії COVID-19 та у період техногенних катастроф. За визначенням BOO3, телемедицина - це метод надання послуг із медичного обслуговування там, де відстань $\epsilon$ критичним чинником. Телемедичні послуги - це дистанційні медичні консультації, консиліуми, контроль фізіологічних параметрів організму пацієнта, проведення діагностичних та лікувальних маніпуляцій, обмін результатами обстеження пацієнта, а також відеоконференції, відеосемінари та відеолекції [4]. За умов боротьби з COVID-19 все більше медзакладів України долучають до формату дистанційних відеоконсультацій, що дозволяє зберегти здоров'я лікарів і пацієнтів, а також взаємодіяти лікарям iз колегами в особливо складних випадках. Це відбувається завдяки ініціативам ІТактивістів, які швидко реагують на виклики часу. Так, у квітні цього року на базі всеукраїнської системи «Поліклініка без черг» впровадили функцію онлайн-консультацій пацієнтів. Попит на телемедицину в Україні лише набирає обертів, що відкриває можливості якісно змінити систему охорони здоров'я в країні [4]. Цей напрямок потребує координації діяльності Міністерства охорони здоров'я України, Міністерства цифрової трансформації України, Національної служби здоров'я України, Міністерства освіти і науки України та ін.

Проведений аналіз дає підстави стверджувати, що існує потреба в координації діяльності органів державної влади, щоб зазначені органи державної влади, з одного боку, «доповнювали» один одного і полегшували власну роботу, а з іншого боку, не дублювали функції один одного, така потреба та необхідність є об'єктивною.

Висновки. У дослідженні здійснено аналіз проблем реалізації механізмів координації діяльності органів державної влади України в умовах пандемії COVID-19. Обгрунтовано, що Національний штаб протидії COVID-19 повинен здійснювати координацію діяльності органів державної влади України в умовах пандемії COVID-19. Визначені основні сфера координації діяльності органів державної влади, зокрема: допомога особам, громадянам (їх колективам, суспільству в цілому) у зв'язку з поширенням захворювання, а також інші дії; допомога приватному бізнесу, який є основою економіки країни; формування прогнозів поширення короновірусної інфекції та наслідків пандемії COVID-19 та створення при Національному штабі протидії 
COVID-19 спеціального підрозділу, який би здійснював форсайт-дослідження; формування дієвої державної інформаційної політики, спрямованої на надання правдивої інформації щодо захворілих осіб, заходи, які здійснюють органи державної влади та місцевого самоврядування для запобігання поширенню короновірусної інфекції та мінімізації наслідків пандемії COVID-19, надання експертних оцінок питання імунізації населення та формування суспільного імунітету; формування єдиних ресурсів по наданню важливих адміністративних послуг он-лайн для населення; формування нормативно-правових засад запровадження телемедицини в Україні як основи забезпечення надання медичних послуг в умовах пандемії COVID-19 та у період техногенних катастроф.

\section{Лimepamypa:}

1. Чорний О.В. Механізми реалізації державної політики в галузі охорони здоров'я під час пандемії COVID-19 на засадах партнерства в суспільно-владній взаємодії. Вчені записки ТНУ імені В.І. Вернадського. Серія: Державне управління. 2021. Том 32 (71). № 2 С. 82-86.

2. Ткачук Р. Пандемія як збурювальний вплив в системі управління екстреним реагуванням. Науковий вісник : Державне управління. 2021. №1 (7). URL: file:///C:/Users/Oksana/Downloads/153-

\%D0\%A2\%D0\%B5\%D0\%BA\%D1\%81\%D1\%82\%20\%D1\%81\%D1\%82\%D0\%B0\%D1\%82\%D $1 \% 82 \%$ D1\%96-428-1-10-20210311.pdf

3. Постанова Верховної Ради України Про заходи протидії поширенню коронавірусної хвороби (COVID-19) та захисту всіх систем життєдіяльності країни від негативних наслідків пандемії та нових біологічних загроз». URL: https://zakon.rada.gov.ua/laws/show/937-20\#Text

4. Запорожан Л. П., Теренда Н. О., Литвинова О. Н., Панчишин Н. Я., Феш М. С. Необхідність розвитку української телемедицини за сучасних умов. Вісник соиіальної гігієни та організації охорони здоров'я України. 2020. № 2 (84). С. 65-71.

\section{References:}

1. Chornyi, O.V. (2021), Mekhanizmy realizatsii derzhavnoi polityky v haluzi okhorony zdorovia pid chas pandemii COVID-19 na zasadakh partnerstva $\mathrm{v}$ suspilno-vladnii vzaiemodii [Mechanisms for implementing public health policy during the COVID-19 pandemic on the basis of partnership in public-government interaction], Vcheni zapysky TNU imeni V.I. Vernadskoho. Seriia: Derzhavne upravlinnia - Scientific notes of TNU named after VI Vernadsky. Series: Public Administration, Tom 32 (71), (2): 82-86. [in Ukrainian].

2. Tkachuk, R. (2021), Pandemiia yak zburiuvalnyi vplyv v systemi upravlinnia ekstrenym reahuvanniam [Pandemic as a disruptive effect in the emergency response management system], Naukovyi visnyk : Derzhavne upravlinnia - Scientific Bulletin: Public Administration, №1 (7). Retrieved from file:///C:/Users/Oksana/Downloads/153-\%D0\%A2\%D0\%B5\%D0\%BA\%D1\%81\% D1\%82\%20\% D1\%81\%D1\%82\%D0\%B0\%D1\%82\%D1\%82\%D1\%96-428-1-10-20210311.pdf [in Ukrainian].

3. Postanova Verkhovnoi Rady Ukrainy Pro zakhody protydii poshyrenniu koronavirusnoi khvoroby (COVID-19) ta zakhystu vsikh system zhyttiediialnosti krainy vid nehatyvnykh naslidkiv pandemii ta novykh biolohichnykh zahroz» [Resolution of the Verkhovna Rada of Ukraine on measures to combat the spread of coronavirus disease (COVID-19) and protect all vital systems of the country from the negative effects of the pandemic and new biological threats]. Retrieved from https://zakon.rada.gov.ua/laws/show/937-20\#Text [in Ukrainian].

4. Zaporozhan, L. P. \& Terenda, N. O. \& Lytvynova, O. N. \& Panchyshyn, N. Ya. \& Fesh M. S. (2020), Neobkhidnist rozvytku ukrainskoi telemedytsyny za suchasnykh umov [The need for the development of Ukrainian telemedicine in modern conditions], Visnyk sotsialnoi hihiieny ta orhanizatsii okhorony zdorovia Ukrainy - Bulletin of social hygiene and health care organization of Ukraine, № 2 (84): 65-71. [in Ukrainian]. 